\title{
A Critical Review of the First Travelogue written in an Indian language on Assam Udāseen Satyashrabār Asam Bhraman by Ramkumar Bidyaratna
}

\author{
Bibha Devi \\ Assistant Professor, Department of English, Indreswar Sarma Academy Degree College, \\ JibanPhukan Nagar, Dibrugarh, Assam. ORCID: oooo-0oo3-0591-8737. \\ Email: bibhadevi@gmail.com
}

\begin{abstract}
Travel narratives usually provide ethnographic information about a place and its inhabitants. The travelogue written in 1881 by Ramkumar Bidyaratna gives an excellent ethnographic account of contemporary Assam and Assamese society of the nineteenth century. The travelogue, which was originally written in Bengali, was translated into Assamese by Munin Sarma in 2014. The book is significant for its prudent comments on various socio-cultural aspects of the Assamese society like - condition of Assamese women, widow remarriage, commerce, religion, etc. As stated in the translated version, Bidyaratna's travelogue was probably the first travelogue on Assam written in an Indian language. There was an aim behind Bidyaratna's travel to Assam. From his experiences from his travel to places outside Bengal he had developed a belief that unless one gets associated with another culture, it is natural to have a wrong notion about that culture. His aim was to eradicate misunderstandings between the Assamese and the Bengalis. In this present study, the Assamese version of the travelogue has been used to explore and interpret the sociocultural milieu of Assam as represented in the narrative. This paper critically reviews the book, firstly, to explore the way ethnographic information about Assam has been represented in it; and, secondly, to generate an understanding of the progressive thinking of the writer as evident from it.
\end{abstract}

Keywords: Travelogue, ethnography, Assam, culture, Assamese

\section{Introduction}

The travelogue Udāseen Satyashrabār Asam Bhraman was published in the year 1881. In the preface of the book the main objective of writing this travelogue has been explicitly stated by the Bengali author Ramkumar Bidyaratna. He writes that the aim is to eradicate the common misconception that existed in the nineteenth century Bengali society regarding the land inhabited by non-Aryans, i.e. Assam. In his travelogue he has endeavoured to understand the Assamese people. His descriptions reflect the natural curiosity of a traveller. What is remarkable in his narrative is the objectivity of his narration. On some social matters he has tried to give an objective explanation. He can be seen playing the role of a social scientist. Bengalis are the target readers of his book. However on some occasions he has also addressed the Assamese readers. In this travelogue, Bidyaratna has succinctly and directly expressed his opinion regarding various societal aspects of the Assamese society. The most important of these are - widow remarriage, educational backwardness, socio-economic condition, and the status of women, etc.

This book contains twenty four sections. It begins with an introduction and an account of his arrival in Assam. He mentions that he started off from Kolkata on 24th of Magha and arrived 
at Dhubri on $20^{\text {th }}$ Sot. After almost two months he reached Assam. At the very beginning, he makes a comment giving a clue about his love for Assam:

For the people of Bengal who love to stay inside their courtyards, Assam is a dangerous place. On hearing the name of this place they get frightened. However, even though I am a Bengali, Assam is dear to me.(Sarma, 2014, p.61; translation mine.)

It can be clearly inferred that the contemporary Bengali society had some prejudiced notion about the Assamese society. For them Assam was a 'dangerous' place. However, from his experiences of travelling different places outside Bengal, Bidyaratna was well aware of the fact that until and unless a person comes in contact with another society, its history and culture, it is natural to have some wrong notion about it. Probably, the reason for this fear was the 'non-Aryan' origin of the people of Assam.

The fear of the outsiders or xenophobia of Assamese people towards outsiders was narrated by Bidyaratna. Once he was travelling through a village in Nagaon of Assam. He became very thirsty. He went to a household and asked for some water to quench his thirst. But, instead of offering him water they asked him to go to the nearby river and drink water. He explains that he was not offered any water as he was a "bongāl", i.e., an outsider. The explanation that Bidyaratna offers for this treatment by the Assamese household gives us clue about his ability to neutrally analyse causes and effects. He gives a neutral account of the attitude of the Bengali towards the Assamese and the Assamese towards the Bengali. He views that the Bengali people hated the Assamese and the latter were jealous of the former. The reason for the dislike by the lower class Assamese society has been explained by him from a historical perspective. He views that after the attack by the Mughals a feeling of dislike for the Bengalis started to develop among the Assamese people. That attack was known as "Bongālār Akraman" (the attack by the Bengalis). This dislike for the Bengalis was further deepened by the uproarious outsiders who later on came to Assam.

In a section on the Brahmana caste, Bidyaratna has devoted a paragraph on the marriage system of the lower-caste Assamese people. According to him, among the lower class few marriages were conducted following the Hindu ritual. Marriages that were conducted following the societal norms were not legally recognised by the government. Therefore, if a woman appealed before the government for leaving her husband, the government permitted her to live separately. In addition, she was ordered to reimburse the money spent during the celebration of the marriage. He also mentions that widow remarriage was also extant in the lower class. Moreover, among the lower class people there were no strict rules or norms for performing the marriage ceremony. He was not very pleased with this lack of strict rules and regulations. Bidyaratna was a Brahmo reformer. Although, the reformations suggested by the Brahmo Samaj were in favour of providing freedom to women to a limited extent, they also welcomed and followed some traditional practices and thinking of the patriarchal Hindu society. In addition, it was not free from the influence of the 'Victorian morality.'

Educational backwardness was another important issue that Bidyaratna has commented on. In his note on "Education in Assam", he has written that during the time of his visit, English education was prevalent in Assam. Here he also refers to the common belief of the Bengali people that the people of Assam were not as intelligent and smart as the Bengali people. He contradicts to this belief on the basis of his travel experience. According to him, the educated youths of Assam liked to imitate the British in all aspects, be it, food habit or attire. Like a social scientist, he explains the reason for the comparative educational backwardness of the Assamese society. He points out that the Bengalis had been receiving English education for several years before the Assamese. However, Bidyaratna was disappointed by the condition of women's education. 
Women's education was not encouraged by the society. He claims that if Assamese women were provided education, the condition of Assamese women would have been even better.

He has also remarked on the folk life of Assam. However, his views were influenced by the intellectuals of that time. In writing the travelogue, Bidyaratna has studied some books as resources. He has realised the significance of Bihu in the community level. But he was not in favour of Bihu. He considered the Bihu dance to be vulgar. Regarding the status of women in the Assamese society, he begins the note with the following words: "Many people express a kind of dislike for the women folk of Assam." (Sarma, 2014, pp. 165) Again, Bidyaratna contradicts this common misbelief on the basis of the experience he had from his association with the Assamese people developed during his three visits to Assam. He claims that the women of Assam were comparatively free. Significantly, he expressed his view that the fact that Assamese women enjoyed freedom in society, their flaw cannot be overlooked. As a member of the Brahmo Samaj, Bidyaratna considered divorce as a sin. The reformation movement initiated by the Brahmo Samaj patronized widow remarriage, but they were against divorce. The author has also mentioned that though the social reformers have failed to bring into practice widow remarriage in Bengal, that practice had been followed in Assam.

In his travelogue, Ramkumar Bidyaratna has compared the contemporary Bengali society with the Assamese society in terms of morality and the status of women. He reiterates that Assamese women are freer than the Bengali women. Referring to various criticisms about Assamese society, he puts forward his argument that the Assamese society is far developed than the Bengali society as the practice of female foeticide was not practiced in the former. Bidyaratna highlights the fact that the women of Assam are strong, smarter than their male counterparts, and brave. Bidyaratna was a minute observer and searcher of knowledge. He closely observed the domestic and social lives of the indigenous people of Assam. From his account the readers get a portrayal of the contemporary society. He was astonished to see how both the husband and wife contributed to the daily domestic activities to run the family smoothly. The women folk of Assam, according to Bidyaratna, actively contributed to the economic life too.

Another interesting aspect that he focused was the sophisticated attire of the Assamese women. Bidyaratna has praised Assamese women for being active and skilful. He writes that the Assamese women of all social classes can weave best quality clothes of different types. In this context, he describes the attire of contemporary Assamese women - a piece of cloth covering the waist to the legs called mekhela, from the waist to the upper body parts were covered by a piece of cloth known as riha. He also informs the reader that whenever Assamese women went to travel to another village they used to cover their body with one additional piece of cloth. They used to wear 'paat' (mulberry silk) and 'muga' silk. Only the widows used to wear cotton clothes.

In Udaseen Satyasrabar Assam Bhraman, Bidyaratna's remarks on the economic status of Assam were very important. In a section devoted to the tea industry in Assam, he has made some important revelations. He states that he has visited many tea gardens in Assam. In these gardens there was a great demand for workers. This demand was met by migrant workers brought from different parts of India. Bengali, Santhali, Hindustani, and Odiya people were brought here for this purpose. However, the saddest part, according to the author is that most of these workers did not come to work in the tea gardens of Assam willingly, nor were they forced by the government. They were brought by some agents. These agents or local recruiters (known as ārākāti) collected such labourers by means of various temptations. The tea gardens of Assam were very unhygienic places to work in. Many of the migrant workers used to die once they arrived there and started to 
work. According to Bidyaratna, the death rate was much more in these gardens. The law for these workers was not followed in most of the cases and so they were ruthlessly exploited.

Furthermore, Bidyaratna opines that the advent of Britishers as business partners of India had many disastrous outcomes. There are many spheres in which India and Assam, in particular, have been affected by the British trade and commerce policies. He is very critical about the opium trade in Assam and in his book he has statistically proven his concern. According to him, even though usage of opium was not unknown in Assam, yet the British policies had encouraged and increased it rampantly.

Finally, in the last section, it can be seen that Bidyaratna is very much elated to find elephants in Assam. According to him, elephants were found in almost all the districts of Assam. Earlier the local people used to capture and elephant trade was very prosperous but the British government policies were not in favour of the local Assamese people.

\section{Conclusion}

To sum up, it can be found from his travel narrative that Ramkumar Bidyaratna portrayed the Assamese society of the late nineteenth century in great details. He presented an account of the Assamese culture and society with a progressive outlook and was successful in maintaining a neutral position in his explanation and comments. However, he was not free from some prevalent notions of that period. He provided data in a very systematic way. In his travelogue he covered almost every aspect of the late nineteenth century Assamese society like, religion, status of women, education, commerce, agriculture, tea industry, etc. He praises the freedom given to women in Assamese society and appreciated the practice of widow remarriage among the lower caste people. He also narrated about the exploitation of migrant workers brought for the tea industry and the ill effect of "Kāni", i.e. opium. In this travelogue, Bidyaratna's disfavour of divorce can also be noticed. Similarly, his comments on Bihu reflect his disapproval of this festival. On the whole, his travelogue was successful in giving an account of the lives of the nonAryans 'dreaded' by the Bengali society.

\section{References:}

Bidyaratna, R. (1881). Udāseen Satyashrabār Asam Bhraman (M. Sharma, Trans. 2014). Guwahati, Students Stores. 